\title{
Roles and Responsibilities of Music Director: A Case Study of Geronimo Radio and Swaragama FM, Yogyakarta
}

\author{
Guntur Eko Prasetyo \\ Music Department, Faculty of Performing Arts, \\ Institut Seni Indonesia Denpasar \\ email: gunturmanagement@gmail.com
}

\begin{abstract}
This article focuses on the roles and responsibilities of a music director on radio stations to understand their roles, responsibilities and the way how he or she works in the radio industry. Radio Geronimo and Swaragama FM in Yogyakarta, Indonesia, were chosen as research locations. This research uses a qualitative method with a case study approach. The findings in this study are the music director has full rights in determining the music that will air on the radio. Music director oversees the running of the types and types of music that are played during broadcasts so as not to break out of the provisions and vision and mission that has been made. The most important thing is, basically a music director and radio plays a role in shaping the musical tastes that develop in the community.
\end{abstract}

Keywords: music director, radio industry, music selection.

\begin{abstract}
ABSTRAK
Artikel ini memfokuskan peran dan tanggungjawab seorang music director pada stasiun radio untuk memahami bagaimana peran, tanggungjawab serta cara kerja mereka di dalam industri radio. Radio Geronimo dan Swaragama FM di Yogyakarta, Indonesia, dipilih sebagai lokasi penelitian. Penelitian ini menggunakan metode kualitatif dengan pendekatan studi kasus. Temuan dalam penelitian ini adalah music director mempunyai hak penuh dalam menentukan musik yang akan mengudara di radio. Music director mengawasi berjalannya jenis-jenis dan macam musik yang diputar saat siaran berlangsung agar tidak keluar dari ketentuan dan visi misi yang telah dibuatnya. Yang paling penting dari itu adalah, pada dasarnya seorang music director dan radio ikut berperan dalam membentuk selera musik yang berkembang di masyarakat.
\end{abstract}

Kata kunci: music director, industry radio, pemilihan lagu.

\section{INTRODUCTION}

Radio is one of the electronic information and entertainment media that is still widely used today. It produces entertainment in the form of sound to be enjoyed by its consumers. Even though it only produces sound without visuals, there are still quite a lot of its enthusiasts, especially music lovers. 
Music is very important to radio stations, and all programs on radio have music content. Every program on a radio station uses music in it. Here we are not only talking about radio but also about music. Good music to be played and enjoyed by the listeners.

Quite a lot of radios are operating in Indonesia, especially in Yogyakarta, Indonesia. Some of the radios that are classified as 'existing' are Geronimo FM, Swaragama FM, JIZ FM, Retjo Buntung FM, and others. Each radio provides a different type of music. Each station plays music according to their character and segmentation. Some of them even play only certain music genres. For example, MBS FM only plays dangdut (one of Indonesia musical styles) and Primary FM only plays Javanese traditional songs.

Radio that plays music with a particular genre does not reach consumers widely and is usually not commercial. Commercial radios with a broad list of listeners, usually play music that is popular on the Indonesian and world music charts. So they can reach wider consumers because the orientation is business and benefit from it. The author takes the example of two radio stations in Yogyakarta which are quite well known and have quite a number of listeners, namely Geronimo FM and Swaragama FM. Radio Geronimo FM and Swaragama FM play many songs that are currently popular, both Indonesian and International songs. So that the radio has an age segment range of 18-30 years, economically this radio segmentation is middle to upper. This radio does not only play Indonesian songs or popular international songs, but also indie songs from local and Indonesian artists are also played on this radio. These two radios were selected as samples because they have the same segmentation. So relatively that there will be no significant differences.

To determine the songs that must be played on air Radio Geronimo FM and Swaragama FM make several selections. The most common thing is to create national charts and international ones. Every week the charts are made to see the level of listener's appreciation for certain songs. These charts will later be chosen to be played in the programs presented.

The charts as described above provide choices of songs to be played in programs created by the radio. But to determine what will be played in a particular event requires another decision. The person who has the authority to decide that is 
the Music director. The music director is the person behind all the songs that ultimately play on a radio.

From the background described above, the author wants to know, how does a music director determine the appropriate music and must be played in a program? Are there considerations used in making choices?

Music in the industrial context should not be seen as mere music phenomena or treated as a mere text phenomenon. But must also be seen in full in relation to other variables such as: the history of the community, geographical conditions, social hierarchy, conflict, education, economy and others.

The music industry uses the media as a mouthpiece for the community for certain interests. What generally happens is the media become a means of publication so that people can hear and appreciate a particular music. The most basic interest in the industrial context is of course economic profit (Williamson \& Cloonan, 2007). Perebinossoff \& Gross (2005) says music content on television and radio is the result of careful research about what the public wants to hear. By knowing what the public wants to hear or following the current evolving tastes, television and radio industry players will benefit economically.

On the other hand, Hendy (2000) through his research on British Broadcasting Corporation (BBC) Radio 1, shows that radio does not always find out what kind of music people want to hear. However, it also helped shape or accompany the people's taste in certain music.

Meanwhile, Ahlkvist \& Faulkner (2002) said that basically music directors on a radio not only find out what people want to hear, but also determine what music should be heard. For this reason a music director often uses public researchers and consultants for this purpose.

Through the five journals above, it can be concluded that the determination of music on the radio is inseparable from the interests of the industry where economic aspects are important objectives. Music selection in the industrial world is based on tastes that are developing in the wider community. They follow market developments to determine all content to be presented. However, as has been explained, not all content in radio is determined by people's taste. The selection and scheduling process of music played by radio personnel also shapes the tastes that will circulate 
in the community. In addition, the decisions of those who have authority in the radio also influence in determining the content.

A music director at least also has knowledge of music science because in determining a song to be played the task of a music director is similar to a music presenter. The goal is that each song that is played can be presented at the right time and opportunity (Lismayanti, 2017).

Radio can also be used to disseminate traditional music or a culture that is about to be popularized in a region. An example is the Bengkulu government not repolving dol music as a means to strengthen Bengkulu community solidarity. This goal can be achieved by the Bengkulu government as well as bringing a positive impact and opening opportunities for artists to work by exploring Bengkulu's local traditional music (Commerce, 2014).

\section{RESEARCH METHODS}

This study uses qualitative methods to answer research questions in depth. While the approach used in this research is a case study. This case study was carried out in two public radios in Yogyakarta which have relatively the same level and segmentation. To obtain data, the author uses in-depth interviews with informants who are seen to have the capacity and understanding of research issues, that is, the role of a music director and the world of radio broadcasting.

The author uses interview guidelines in the form of questions about the points of some focus issues. These interview guidelines are intentionally made in a rigidly unstructured manner so that informants are more free and free to convey information without being tied to the arrangement of written questions. In conducting interviews, there are questions that are spontaneous so that there are some questions that come out of the interview guidelines. However, it actually helps the author in exploring the data that is needed.

In qualitative research, researchers are important instruments related to research data as well as instruments that select, examine, and interpret research data. Resource persons in this study are those who have a role in determining music in Geronimo FM Radio and Swaragama FM, namely, Awang Adjiewasita as music director of Geronimo FM radio, Bonny as music director in Swaragama FM, Iyan Narendra as producer, Aloysia Clara and Stefanus Firman as the announcer. The 
interview was conducted at Geronimo FM which is located on Jalan Gayam 24, Baciro, Gondokusuman, Yogyakarta, on 5 April 2017. Interviews were also conducted at Swaragama FM which is located in the UGM roundabout complex on 10 April 2017. Interviews with producers were conducted at one of the malls in Yogyakarta, on 20 April 2017. An interview with the announcer was conducted at one of the cafes on Jalan Sudirman Yogyakarta on April 3, 2017 and May 16, 2017.

\section{DISCUSSION}

A music director in the world of radio broadcasting is the person determining the type of music and songs that will be played in broadcasts. A simple music director that determines whether or not it's appropriate, whether or not a type $A$ music/song is played in program $B$ and at certain times. They also oversee the music that is played when broadcasting so as not to break out of the provisions. Music director is also a bridge between record companies and radio companies and listeners. According to the data obtained, the author divides into three concepts in line with the research question to be obtained, which is to find out how to determine the appropriate music to be played when broadcasting.

\section{Reference in Defining Music on Radio}

Talking about radio means talking about music because radio covers more than $50 \%$ is music so that the selection of music is crucial in the radio industry. From the data obtained through interviews; there are many things that need to be considered to determine a music playing on air on the radio. Radio Geronimo FM and Swaragama FM are commercial radios with many programs. Every day the two radios have different programs.

Basically this radio does not limit the type of music that will be played. But the music director determines music according to the type of program in each program, which is adjusted according to the program's broadcast time too. This includes segmentation of targeted listeners. The type of program and show time determine how the music director chooses the music to be played. A music director gives a list of collections of songs that have been selected to be played in a broadcast program. After the list is created, the host or broadcaster has full authority to determine the 
order of songs that are played based on a list that has been created by the music director.

On the other hand, radio broadcasters facilitate the public's taste from the many requests for certain songs. It was from the listener's request that they decided that certain songs became top hits or in other words the songs that were most in demand by the public. There has never been any research conducted to see the tastes that are developing in the community, so what they call the tastes of the community is relatively conjectural. Taste that develops in society is one of the constructions made by the radio industry.

Market segmentation targeted by Geronimo FM radio and Swaragama FM are students and workers. Therefore the program and the selection of music is packaged according to segmentation. Personnel in Geronimo FM radio and Swaragama FM often do training so that they have the same tastes and mindset so that when they are hosting a program or making a song list it can be in accordance with the character of the radio.

\section{Music is Determined Due to Policy}

In the case of Radio Geronimo and Swaragama, a music director basically did not conduct research in a strict manner to find out what was needed by the listeners. Often in determining a music, music director discuss with the show's producer, and announcer. However, not all programs have producers. What often happens is, an announcer also doubles as a producer.

The ideas of producers and broadcasters become one of the considerations of music directors in determining music. The radio director does not take part in determining the music that will be played regularly. If there is something that makes the company get a greater profit, usually the leader of the company will take part in giving these considerations.

In determining music, a music director does not merely speak of certain qualities or values of music. Profit orientation in the industrial world is of course a special consideration. Thus a music director tends to see the whole music, including the economic factors influential in determining music. When a record company or indie industry holds a new song promo and gives a fee to the radio company, they will get priority even if not complete yet. 


\section{Skills in Defining Music}

A radio announcer also has a role in determining the music that will be played in a broadcast. He or she has the responsibility to play songs from a list that has been created by the music director when on air. Therefore, when training as radio broadcasters, they are required to be given knowledge about the types of music and their segmentation. Geronimo FM Radio places listeners as potential participants, to win sympathy. This sympathy can be group or certain communities. For this reason, a radio announcer needs sufficient knowledge capital and intuition about music and its segmentation.

A broadcaster's training in determining the music played, is obtained through the music director. Thus there is a common perception between the two. Thus a music director must have good knowledge and intuition. So that you can put music in a program not only well but on target.

Music determined in a radio program does not fully follow the tastes of the people. But radio also plays a role in shaping musical tastes in a society. Radio also functions to sell products from record label companies. That is, a radio music director also has a big role in shaping people's tastes.

\section{CONCLUSION}

It can be concluded that a music director in a radio plays a role in determining the music that will be played in a program. He or she made a list of songs that would be handed over to an announcer to be chosen when broadcast on air. In addition they also oversee the music that is played when the broadcast takes place so as not to come out of the provisions that have been made based on the considerations of the vision of the radio mission and economic profit factors. Another factor that influences the choice of type and style of music is listener segmentation. This segmentation can be in the form of social level, age, and type of work, type of programs, time of the program.

The experience and knowledge of the personnel of a radio is also a factor that often also determines the music chosen and played. As well as people who have more authority, no big influence in determining music. Basically the tastes that 
develop in society have been constructed by radio media. The radio industry does not fully follow the wishes of the community in determining music.

\section{REFERENCES}

Ahlkvist, J. A; Fisher, G. 2000. "And the Hits just Keep on Coming: Music Programming Standardization in Commercial Radio". Poetics, 27(5-6), 301325. https://doi.org/10.1016/S0304-422X(00)00007-3

Ahlkvist, J; Faulkner, R. 2002. "Will This Record Work for Us?": Managing Music Formats in Commercial Radio". Qualitative Sociology, 25(2), 189-215. https://doi.org/10.1023/A:1015494716804

Hendy, D. 2000. "Pop Music Radio in the Public Service". Media, Culture \& Society, 22, 743-761. https://doi.org/10.1177/016344300022006003

Lismayanti, R. 2017. "Pertunjukan Solo Vokal dengan Repertoar La Traviata, Caro Nome, Ya Maulai, I Have Nothing, dan Mengapa". Laga-Laga: Jurnal Seni Pertunjukan ISI Padang Panjang, 1(2 September 2017), 86-91. http://dx.doi.org/10.26887/lg.v1i2.260.g233

Niaga, I. 2014. Jurnal Ekspresi Seni Jurnal IImu Pengetahuan dan Karya Seni, 16, $51-64$.

Perebinossoff, Philippe; Brian Gross, L. G. 2005. Programming for TV, Radio, and the Internet: Strategy, Development, and Evaluation. Focal Press.

Williamson, J; Cloonan, M. 2007. "Rethinking the Music Industry". Popular Music, 26(2), 305-322. https://doi.org/10.1017/S0261143007001262. 